\title{
Keefektifan Model Picture And Picture Berbantu Media Flashcard Terhadap Keterampilan Menulis Karangan
}

\author{
Ringga Dwi Anggraini ${ }^{*}$, Ikha Listyarini² ${ }^{2}$ Choirul Huda ${ }^{3}$ \\ 1,2,3Jurusan PGSD Fakultas Ilmu Pendidikan Universitas PGRI Semarang
}

\section{A R T I C LEINFO \\ Article history: \\ Received 18 Desember 2017 \\ Received in revised form 30 Desember 2017 Accepted 15 Januari 2018 \\ Available online 20 \\ Februari 2018}

\section{Kata Kunci:}

model picture and picture media flashcard,

keterampilan menulis

karangan

Keywords: model picture and picture, media flashcard, writing skill.

\begin{abstract}
A B S T R A K
Tujuan dari penelitian ini adalah untuk mengetahui keefektifan model Picture and Picture berbantu media Flashcard terhadap keterampilan menulis karangan siswa kelas IV SD Negeri Kalibanteng Kidul 03 Semarang. Latar belakang yang mendorong peneliti melakukan penelitian tersebut, karena para siswa masih banyak yang belum mampu menulis karangan secara optimal. Hal tersebut dikarenakan kurangnya pembelajaran yang efektif dan masih menggunakan metode konvensional yang cenderung membuat siswa menjadi bosan. Dilihat pada keterampilan menulis karangan siswa, jenis penelitian ini adalah penelitian kuantitatif dalam bentuk Nonquivalent Control Group Design, dengan jenis Pretest-Posttest Control Group Design. Populasi dalam penelitian ini adalah seluruh siswa kelas IV di SD Negeri Kalibanteng Kidul 03 Semarang. Adapun pengambilan sampel dalam penelitian ini yaitu dengan menggunakan sampling jenuh. Data dalam penelitian ini diperoleh melalui tes tertulis, wawancara, dan dokumentasi. Hasil analisis terhadap ketrampilan menulis karangan siswa kelas IV SD Negeri Kalibanteng Kidul 03 Semarang yang dihitung menggunakan Uji t diperoleh hasil rata - rata nilai kelas ekperimen 75,000 dengan thitung sebesar 3,086053 dan ttabel sebesar 2,000, karena thitung > ttanel yaitu 3,086053 >2,000 maka dapat disimpulkan bahwa Ha diterima. Hal ini berarti bahwa hasil belajar siswa yang mendapat pembelajaran menggunakan model pembelajaran Picture and Picture berbantu media Flashcard lebih baik daripada menggunakan model konvensional
\end{abstract}

\section{A B S T R A C T}

The purpose of this study was to determine the effectiveness of Picture and Picture models assisted by Flashcard media on essay writing skills of fourth grade students of SD Negeri Kalibanteng Kidul 03 Semarang. The background that encourages researchers to do the research, because there are still many students who have not been able to write essays optimally. This is due to the lack of effective learning and still using conventional methods that tend to make students bored. Judging from the students' writing skills, this type of research is quantitative research in the form of Nonquivalent Control Group Design, with the type of Pretest-Posttest Control Group Design. The population in this study were all fourth grade students in SD Negeri 03 Kalibanteng Kidul Semarang. The sampling in this study is by using saturated sampling. The data in this study were obtained through written tests, interviews, and documentation. The results of the analysis of essay writing skills of fourth grade students of Kalibanteng Kidul State Elementary School 03 Semarang, calculated using the t test, obtained the average results of the experimental class 75,000 with tcount of 3.086053 and ttable of 2,000 , because tcount $>$ tlanel is $3.086053>2,000$ it can be concluded that $\mathrm{Ha}$ is accepted. This means that the learning outcomes of students who get learning using Picture and Picture learning models assisted by Flashcard media are better than using conventional models 


\section{Pendahuluan}

Pembelajaran adalah proses interaksi antarsiswa dan antarsiswa dengan guru dan sumber belajar pada suatu lingkungan belajar (Permendikbud, 2014). Proses pembelajaran pada satuan pendidikan diselenggerakan secara interaktif, inspiratif, menyenangkan, menantang, memotivasi siswa untuk berperan aktif, serta memberikan ruang yang cukup bagi prakarsa, kreativitas, dan kemandirian sesuai dengan bakat, minat, perkembangan fisik serta psikologis siswa.

Keterampilan berbahasa di Sekolah Dasar terdiri atas keterampilan berbahasa tulis dan keterampilan berbahasa lisan. Klasifikasi ini dibuat berdasarkan pendekatan komunikatif. Implikasinya, pemelajaran bahasa di Sekolah Dasar harus difokuskan pada kemampuan siswa memahami dan menggunakan bahasa sebagai alat komunikasi dalam kehidupan sehari-hari.

Kegiatan menulis diharapkan dapat menyampaikan pesan, gagasa, ide, karangan, perasaan melalui tulisan yang selanjutnya akan diterima oleh pembaca. Maka dari itu, untuk meningkatkan keterampilan menulis dibutuhkan media yang dapat menunjang kreativitas dan keterampilan menulis seseorang. Dalam proses karang-mengarang setiap ide perlu di libatkan pada suatu kata, kata-kata dirangkai menjadi sebuah kalimat membentuk paragraf, dan paragraf-paragraf akhirnya mewujudkan sebuah karangan. Menulis sebuah karangan adalah bukan kegiatan yang gampang atau sederhana melainkan kegiatan yang membutuhkan daya pikir dan motivasi.

Dalam proses pembelajaran kelas VI, guru menggunakan metode ceramah dan tidak diberikan media pembelajaran yang menarik, sehingga membuat siswa menjadi bosan, ramai sendiri, jenuh dan tidak bersemangat. Selain itu masih banyak siswa yang hasil belajarnya rendah sehingga tidak sesuai dengan KKM (Kriteria Ketuntasan Minimal) yaitu 75 yang terdiri 22 siswa dari 26 siswa yang tidak tuntas, sehingga presentasenya $84,6 \%$ siswa yang tidak tuntas dan $15,4 \%$ siswa yang tuntas. Selain itu ada permasalahan yang muncul dari dalam diri siswa yaitu kurangnya motivasi siswa untuk berlatih menulis, ketidaktauan siswa mengenai apa yang akan dituliskan karena kesulitan untuk memulai tulisan itu dari mana. Hal itu menjadi sebuah tantangan bagi guru untuk menciptakan kelas yang nyaman, menyenangkan dan disukai oleh siswa, terutama dalam kegiatan pembelajaran menulis.

Cara yang bisa dilakukan guru untuk bisa menciptakan pembelajaran yang menyenangkan namun dapat mencapai tujuan pembelajaran adalah melalui penggunaan model yang inovatif yaitu model Picture and Picture dan media pembelajaran yang menarik, kreatif sehingga akan membuat siswa menjadi penasaran yaitu media pembelajaran kartu bergambar atau biasa disebut Flashcard.

Menurut Shoimin (2014: 122) model pembelajaran Picture and Picture adalah suatu model belajar menggunakan gambar dan dipasangkan atau diurutkan menjadi urutan yang logis. Model picture and picture merupakan model pembelajaran yang dapat meningkatkan motivasi belajar siswa (Fauzi 2011). Model example non-example merupakan model pembelajaran pemprosesan informasi yang berbasis komuni-katif (Rini, 2018). Model pembelajaran picture and picture merupakan sebuah model pembelajaran yang menggunakan gambar yang dipasangkan secara logis, jadi guru harus menyiapkan media gambar yang menjadi media utama dalam pembelajaran ini (Mantira, 2017). Pebriana (2017) mengatakan hal yang sama bahwa pembelajaran Picture and Picture ini siswa dituntut harus bertanggung jawab atas segala sesuatu yang dikerjakan dalam kelompoknya. Model pembelajaran Picture and Picture termasuk dalam teori belajar kognitif, dikarenakan dalam proses pembelajarannya banyak melibatkan siswa dan bekerja dalam kelompok, sehingga tidak hanya guru yang aktif melainkan siswa juga aktif (Prihatiningsih, 2018).

Model pembelajaran Picture and Picture mengandalkan gambar yang menjadi faktor utama dalam proses pembelajaran (Riyono, 2015). Model pembelajaran picture and picture mengupayakan siswa untuk belajar secara aktif, berangkat dari pengalaman siswa dan mengajak siswa untuk berpikir kritis (Wulandari,2018). Maka dari itu, sebelumnya guru sudah menyiapkan kartu atau carta dalam ukuran besar. Gambar sangat penting digunakan untuk memperjelas pengertian. Melalui gambar, siswa mengetahui hal-hal yang belum pernah dilihatnya. Gambar dapat membantu guru dalam mencapai tujuan instruksional karena selain merupakan media yang murah dan mudah diperoleh, juga dapat meningkatkan keaktifan siswa. Selain itu, pengetahuan dan pemahaman siswa menjadi lebih luas, jelas dan tidak mudah dilupakan. Model kooperatif tipe picture and picture ini menggunakan pendekatan kontekstual yang merupakan konsep belajar yang membantu guru mengaitkan antara materi yang diajarkan dengan situasi dunia nyata siswa dan mendorong siswa membuat hubungan antara pengetahuan yang dimilikinya dengan penerapanya dalam kehidupan mereka sebagai anggota keluarga dan masyarakat. Sehingga diharapkan dapat membantu siswa memahami pelajaran dan bisa mengaplikasikannya dalam kehidupan sehari hari.Dengan konsep itu, hasil pembelajaran yang lebih bermakna bagi siswa (Ulfa, 2018). 
Agar kegiatan belajar-mengajar tidak monoton dan siswa dapat berkomunikasi menggunakan bahasa Indonesia, baik secara lisan maupun tulisan, diperlukan media dalam proses pembelajaran. Salah satunya dengan media gambar atau Flashcard karena dengan adanya media tersebut dapat memacu imajinasi dan keterampilan siswa dalam menuangkan gagasan. menurut Arsyad dalam Angreany dan Saud (2017: 140) "Flashcard adalah kartu kecil yang berisi gambar, teks, atau tanda simbol yang mengingatkan atau menuntun siswa kepada sesuatu yang berhubungan dengan gambar. Flashcard berukuran 8x12 cm, atau dapat disesuaikan dengan besar kecilnya kelas yang dihadapi." Flashcard atau kartu kilas adalah suatu kartu bolak balik yang sangat ampuh digunakan untuk mengingat dan kaji ulang proses belajar (Heri, 2018). Banyak orangtua yang membelikan anak untuk proses belajar menegenal nama-nama huruf, angka, binatang, buah-buahan, dan pengetahuan umum dasar lainnya (Windura, 2010). Media Flashcard juga dapat didefinisikan suatu media pembelajaran dalam bentuk kartu bergambar yang berukuran $25 \times 30 \mathrm{~cm}$. Gambar-gambarnya dibuat menggunakan tangan atau foto, atau memanfaatkan gambar foto yang sudah ada yang ditempelkan pada lembaran-lembaran flashcard. Gambar-gambar yang ada pada flashcard merupakan rangkaian pesan yang disajikan dengan keterangan setiap gambar yang dicantumkan pada bagian belakangnya. Selain memudahkan anak untuk mengetahui nama sebuah benda, flashcardjuga mampu mengembangkan kemampuan kognitif anak dengan baik dan anak dapat mengembangkan segenap potensi yang dimiliki sesuai dengan kemampuannya. (Susilana \& Riyana, 2007).

Penggunaan media Flashcard dalam pembelajaran merupakan suatu proses, cara menggunakan kartu belajar yang efektif berisi gambar, teks, atau tanda simbol untuk membantu mengingatkan atau mengarahkan siswa kepada sesuatu yang berhubungan dengan gambar, teks, atau tanda simbol yang ada pada kartu, serta merangsang pikiran dan minat siswa dalam meningkatkan kecakapan pengenalan simbol bahan tulis dan kegiatan menurunkan simbol tersebut sampai kepada kegiatan siswa memahami arti/makna yang terkandung dalam bahan tulis.

Tujuan penelitian ini adalah untuk mengetahui keefektifan model Picture and Picture berbantu media Flashcard terhadap keterampilan menulis karangan siswa kelas IV SD Negeri Kalibanteng Kidul 03 Semarang. Berdasarkan latar belakang di atas maka akan dilakukan penelitian dengan judul "Keefektifan Model Picture and Picture Berbantu Media Flashcard terhadap Keterampilan Menulis Karangan Siswa Kelas IV SD Negeri Kalibanteng Kidul 03 Semarang".

\section{Metode}

Jenis penelitian yang digunakan dalam penelitian ini adalah metode kuantitatif. Melalui metode kuantitatif, penelitian ini menggunakan metode eksperimen. Metode penelitian eksperimen merupakan metode penelitian yang digunakan untuk mencari pengaruh perlakuan tertentu terhadap yang lain dalam kondisi yang terkendalikan (Sugiyono, 2011: 72). Pada penelitian ini peneliti menggunakan desain Nonquivalent Control Group Design, dengan jenis Pretest-Posttest Control Group Design.

Setiap penelitian populasi selalu digunakan untuk mengetahui subyek atau obyek apa yang akan diteliti. Adapun populasi dari penelitian ini adalah semua siswa kelas IV di SD Negeri Kalibanteng Kidul 03 Semarang. Sampel yang akan digunakan dalam penelitian ini sebanyak 2 kelas yang berjumlah 26 untuk siswa kelas IVA dan 26 untuk siswa kelas IVB. Dimana pembelajaran untuk kelas IVA yang diberikan perlakuan menggunakan model Picture and Picture dan media Flashcard, sedangkan untuk kelas IVB tidak diberikan perlakuan dan hanya menggunakan pembelajaran konvensional.

Pada penelitian ini peneliti menggunakan teknik sampling Nonprobability Sampling dengan jenis Sampling Jenuh, karena semua anggota populasi dijadikan sampel dengan menentukan terlebih dahulu kelas yang akan dijadikan kelas kontrol dan eksperimen (Sugiyono, 2011: 81-85).

\section{Hasil dan Pembahasan}

Dari data awal yang diperoleh dari nilai pretest yang dianalis dengan uji liliefors untuk mengetahui kenormalan data dari kelas yang akan digunakan untuk penelitian yaitu pada kelas ekperimen yaitu kelas IVA dan kelas kontrol yaitu kelas IVB. Pada kelas eksperimen $\mathrm{L}_{\text {tabel }}$ pada tabel lilifors yaitu 5\% dan n sebesar 26 maka diperoleh $\mathrm{L}_{\text {tabel }}$ sebesar 0,173 dan didapatkan $\mathrm{L}_{0}$ sebesar 0,156. maka 0,156 $<0,173$ maka $\mathrm{H}_{0}$ diterima. Sedangkan pada kelas kontrol dengan tabel liliefors dengan tingkatan signifikan $5 \%$ dan n sebesar 26 sehingga diperoleh $\mathrm{L}_{\text {tabel }}$ 0,173 dan didapatkan $\mathrm{L}_{0}$ sebesar 0,115 maka $0,115<0,173$ maka $\mathrm{H}_{0}$ diterima. Berdasarkan hasil uji normalitas data awal tersebut dapat disimpulkan bahwa kedua populasi berdistribusi normal. Kemudian kedua data diuji menggunakan data yang diuji menggunakan uji $\mathrm{F}$ untuk mengetahui homogenitas variansnya. Diperoleh varians kelompok kelas ekperimen $=11,60239$ dan varians pada kelas kontrol $=12,34753$ dengan $F_{\text {hitung }}=0,939652$ dan $F_{\text {tabel }}$ 
= 1,96. Berdasarkan uji $\mathrm{F}$ didapatkan kesimpulan yang diperoleh dari uji homogenitas awal pada kelas ekperimen dan kelas kontrol adalah bahwa dari kelas ekperimen dan kelas kontrol berasal dari populasi yang homogen.

Pada analisis data akhir dengan uji liliefors untuk mengetahui kenormalan dari kelas ekperimen dan kelas kontrol. Berdasarkan perhitungan uji normalitas pada kelas ekperimen diperoleh $L_{h i t u n g}=0,144$ dan $\mathrm{L}_{\text {tabel }}=0,173$ diperoleh dari daftar tabel liliefors dengan $\mathrm{n}=26$ dan taraf signifikan 5\% sehingga dapat disimpulkan bahwa $\mathrm{L}_{\text {hitung }}<\mathrm{L}_{\text {tabel }}$ yaitu maka $\mathrm{H}_{0}$ dierima. Sedangkan pada kelas kontrol diperoleh $\mathrm{L}_{\mathrm{hitung}}=$ 0,117 dan $\mathrm{L}_{\text {tabel }}=0,173$ diperoleh dari daftar tabel liliefors dengan $\mathrm{n}=26$ dan taraf signifikan $5 \%$ sehingga dapat disimpulkan bahwa $\mathrm{L}_{\text {hitung }}<\mathrm{L}_{\text {tabel }}$ yaitu maka $\mathrm{H}_{0}$ dierima. Berdasarkan hasil tersebut dapat dikatakan bahwa sampel dari kelas ekperimen dan kelas kontrol berdistribusi normal. Kemudian kedua data diuji $\mathrm{F}$ untuk mengetahui tingkat homogenitas variansnya. Berdasarkan perhitungan uji homogenitas dari data awal kelas ekperimen dan kelas kontrol, diperoleh varians kelompok kelas ekperimen = 15,23155 dan varians kelas kontrol $=20,97251$ dengan $F_{\text {hitung }}=0,726262$ dan Ftabel $=1,96$. Kesimpulan yang diperoleh dari uji homogenitas akhir pada kelas ekperimen dan kelas kontrol adalah bahwa dari kelas ekperimen dan kelas kontrol berasal dari populasi yang homogen.

Berdasarkan data analisis awal dan akhir untuk mengetahui tingkat ketuntasan hasil belajar siswa digunakan uji rata-rata dua pihak yaitu diperoleh hasil rata - rata nilai kelas ekperimen sebesar 75 dan rata-rata nilai kelas kontrol sebesar 60 dengan $t_{\text {hitung }}$ sebesar 3,086053 dan $t_{\text {tabel }}$ sebesar 2,000 dengan derajat kebebasan 50 dan taraf signifikan 5\% sehingga dapat diperoleh $t_{\text {hitung }}=3,086053>t_{\text {tabel }}=2,000$ artinya Ho ditolak dan Ha diterima maka dapat disimpulkan bahwa hasil keterampilan menulis karangan menggunakan model Picture and Picture berbantu media Flashcard efektif dan terdapat perbedaan daripada menggunakan model konvensional.

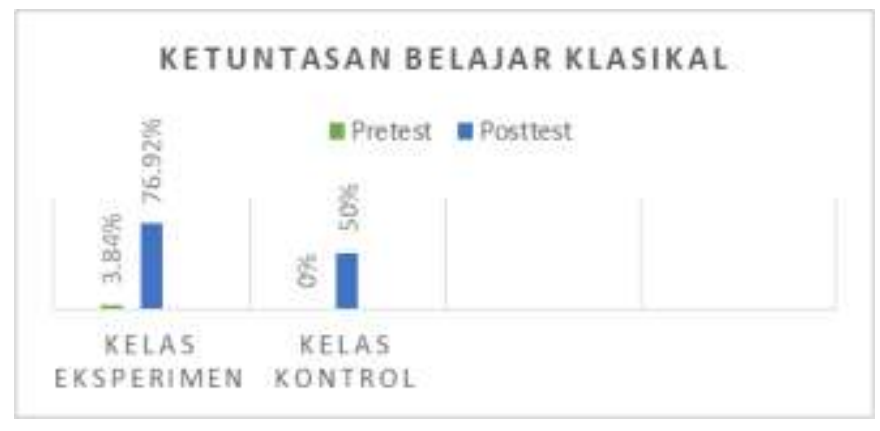

Gambar 1. Diagram Ketuntasan Belajar Klasikal

Dari hasil perhitungan tersebut model pembelajaran Picture and Picure berbantu media Flashcard dapat meningkatkan hasil belajar siswa ditinjau dari keterampilan menulis karangan. Pada proses pembelajaran di kelas eksperimen siswa lebih berpartisipasi dalam menulis. Berbeda dengan siswa yang menggunakan model pembelajaran konvensional, pada proses pembelajaran siswa dikelas kontrol siswa cenderung malas menulis sehingga siswa tidak mampu mengembangkan keterampilan menulis mereka.

\section{Simpulan dan Saran}

Berdasarkan rumusan masalah, analisis data penelitian dan pembahasan, maka peneliti membuat kesimpulan bahwa Model pembelajaran Picture and Picture berbantu media Flashcard efektif terhadap keterampilan menulis karangan pada siswa kelas IV SD Negeri Kalibanteng Kidul 03 Semarang hal ini ditunjukkan bahwa thitung sebesar 3,086053 sedangkan ttabel 2,000 dengan taraf signifikan 5\% karena thitung > ttabel yaitu 3,086053 > 2,000 artinya H0 ditolak dan Ha diterima. Maka dapat dikatakan efektif hal ini dapat dilihat adanya peningkatan hasil belajar siswa banyak yang mendapatkan nilai diatas KKM > 75.

Dari hasil paparan diatas maka perlu adanya beberapa saran yang harus disampaikan, yakni seorang guru harus mampu memberikan motivasi kepada siswanya untuk selalu bersemngat dalam mengikuti pembelajaran, tantangan bagi setiap guru adalah terus berkembangnya zaman, seorang guru juga dituntut untuk selalu mengikuti arus modernisasi sehingga siswa yang diajarnya tidak merasa bahwa gurunya itu jadul (jaman dulu) shingga siswa merasa kurang bersemangat dalam belajar. Dari itu penggunaan model-model yang sesuai dengan karakter siswa dan tingkatan usianya juga menjadi pengaruh terhadap motivasi belajar yang mengarah pada prestasi belajar siswa. Maka penulis 
menyarankan untuk setiap pembelajaran menggunakan model yang bervariasi sehingga siswa tidak merasa jenuh.

\section{Daftar Rujukan}

Angreany, Femmy dan Syukur Saud. 2017. "Keefektifan Media Pembelajaran Flashcard Dalam Keterampilan Menulis Karangan Sederhana Bahasa Jerman Siswa Kelas Xi Ipa Sma Negeri 9 Makassar". Eralingua Jurnal Pendidikan Bahasa Asing dan Sastra, 1 (2): 140-141. Diakses 08 Juli 2018.

Fauzi R. 2011. Penerapan Metode Pembelajaran Picture and Picture untuk Meningkatkan Motivasi Belajar Biologi Siswa Kelas VIII D SMPN 14 Surakarta Tahun Pelajaran 2011/2012. Jurnal Pendidikan Biologi,3 (3): 72-78

Heri, M. and Ariana, P.A., 2018. Pengaruh Media Flashcard Terhadap Kemampuan Kognitif Anak Usia 3-4 Tahun Di Tpa Yayasan Pantisila Paud Santo Rafael Singaraja. Midwinerslion Jurnal Kesehatan, 3(2), pp.221-227.

Mawardi \& Sari, Desty Lusia. 2015. Keefektifan Model Pembelajaran Picture and Picture dan Make a Match Ditinjau Dari Hasil Belajar Dalam Pembelajaran IPA Kelas 4 SD Gugus Mawar-Suruh. Scholaria, 5 (3), 82-99.

Mantira, Zhera. 2017."Pengaruh Model Pembelajaran Picture And Picture terhadap Kemampuan Berpikir Kritis siswa" PESAGI : Jurnal Pendidikan dan Penelitian Sejarah. Vol. 5 No.3 Tahun 2017.

Palguna, Putu Ngurah Dwija, Ni Nyoman Garminah, Dewa Nyoman sudana. 2015. Penerapan Metode Picture and Picture Berbantuan Media Gambar Beseri Untuk Meningkatkan Keterampilan Menulis Narasi. Mimbar PGSD, 3 (1).

Pebriana, Gede Risa, Dibia, I Ketut, \& Ndara Tanggu Rendra. 2017. Penerapan Model Pembelajaran Picture and Picture Untuk Meningkatkan Aktivitas Dan Hasil Belajar IPA Kelas V. Mimbar PGSD, 7 (1), 110.

Peraturan Menteri Pendidikan dan Kebudayaan Republik Indonesia Nomor 103 Tahun 2014 Tentang Pembelajaran pada Pendidikan Dasar dan Pendidikan Menengah.

Prasetyo, E., Widyawati, S., Masykur, R. and Putra, F.G., 2018. Pengaruh pembelajaran picture and picture (PaP) terhadap hasil belajar matematika ditinjau dari kecerdasan spasial. Beta: Jurnal Tadris Matematika, 11(1), pp.50-61.

Prihatiningsih, E. and Setyanigtyas, E.W., 2018. Pengaruh Penerapan Model Pembelajaran Picture And Picture Dan Model Make A Match Terhadap Hasil Belajar Siswa. Jurnal Pendidikan Sekolah Dasar, 4(1), pp.1-14

Purwoko, R., 2018. Penerapan Model Group Investigation Dengan Media Flashcard Untuk Meningkatkan Hasil Belajar Ips Tentang Kegiatan Ekonomi Pada Siswa Kelas Iv Sd Negeri 2 Depokrejo Tahun Ajaran 2017/2018 (Doctoral dissertation, Universitas Sebelas Maret).

Rini, S.E.S. and Utami, S.P.T., 2018. Keefektifan Model Example Non-Example Dan Model Picture And Picture Dalam Pembelajaran Menyajikan Teks Deskripsi Menggunakan Media Gambar Bertema Objek Wisata Sejarah Pada Peserta Didik Kelas VII MTs. Jurnal Pendidikan Bahasa dan Sastra Indonesia, 7(1), pp.48-54.

Riyono, B. and Retnoningsih, A., 2015. Efektivitas model pembelajaran picture and picture dengan strategi inkuiri terhadap motivasi dan hasil belajar siswa. Journal of Biology Education, 4(2).

Shoimin, Aris. 2014. 68 Model Pembelajaran Inovatif dalam Kurikulum 2013. Yogyakarta: Ar-Ruzz Media.

Sugiono. 2011. Metode Penelitian Kuantitatif, Kualitatif, dan R\&D. Bandung:Alfabeta

Susilana \& Riyana. 2007. Media Pembelajaran Hakikat, Pengembangan, Pemanfaatan, dan Penilaian. Bandung: CV Wacana Prima 
Tohriah, T. and Rati, N.W., 2018. Penerapan Model Picture and Picture Berbantuan Media Audio-Visual Untuk Meningkatkan Hasil Belajar Bahasa Indonesia Siswa Kelas II. Journal of Education Action Research, 2(4), pp.340-347.

Trisnanti, I.A.N.L., Tirtayani, L.A., Psi, S., Psi, M. and Putra, I.K.A., 2018. Pengaruh Media Flashcard Bilingual Terhadap Kemampuan Kosakata Bahasa Inggris Permulaan Anak Kelompok B TK Gugus Mawa Kecamatan Denpasar Selatan Tahun Pelajaran 2017/2018. Jurnal Pendidikan Anak Usia Dini Undiksha, 6(1).

Ulfa, S.M., Sabrun, S. and Agusfianuddin, A., 2018. Penerapan Model Pembelajaran Kooperatif Tipe Picture And Picture Dengan Media Flash Card Untuk Meningkatkan Hasil Belajar Matematikasiswa Kelas Viia Smpn 3 Sikur Pada Materi Pokok Pecahan Tahun Pelajaran 2016/2017. Jurnal Media Pendidikan Matematika, 5(1), pp.100-105.

Windura, S. 2010. Memory Champion School. Jakarta: Gramedia

Wulan, Luh Inten Cahya Wulan, Wirya Nyoman, Nyman Jampel. 2014. "Penerapan Model Pembelajaran Contoh non-Contoh Berbantu-tahun Media Papan Planel untuk Meningkatkan Perkembangan Kognitif Anak di TK Pradnya Pramita Kecamatan Tabanan". E - jurnal PG - PAUD Universitas Pendidikan Ganesha Jurusan Pendidikan Guru PAUD, volume 2 No. 1 tahun 2014. 